\title{
D2 LYMPHADENECTOMY WITH PARA-AORTIC SAMPLING IMPROVES LYMPH NODE STAGING FOR GASTRIC CANCER
}

\section{Linfadenectomia D2 com amostragem para-aórtica melhora o estadiamento linfonodal do câncer gástrico}

\author{
Bruno José Queiroz SARMENTO, Alexandre Menezes BRITO, Daniela Medeiros Milhomem CARDOSO, \\ Paulo Moacir de Oliveira CAMPOLI, Osterno Queiroz da SILVA, Jales Benevides SANTANA-FILHO, \\ Paulo Adriano de Queiroz BARRETO, Melissa G. MACHADO, Adalzizio Vieira A-FILHO, \\ Eliane Duarte MOTA, Orlando Milhomem da MOTA
}

Sarmento BJQ, Brito AM, Cardoso DMM, Campoli PMO, Silva OQ, Santana-Filho JB, Barreto PAQ, Machado MG, A-Filho AVA, Mota ED, Mota OM. D2 lymphadenectomy with para-aortic sampling improves lymph node staging for gastric cancer. ABCD Arq Bras Cir Dig 2007 20(3):161-4.

ABSTRACT - Background - An important aspect dealing with gastric cancer is the role of lymphadenectomy in gastric cancer staging. Aim - To verify if lymphadenectomy with stations separation increases the number of dissected lymph nodes and establish comparison between TNM 2002 and JGCA 1998 evaluating lymph nodal status (N). Methods - This is a retrospective analysis of the patients that underwent curative gastrectomy and D2 dissections for adenocarcinoma between 2004 and 2006. Between January of 2004 and June of 2005 (group 1), lymphadenectomy was performed en-bloc with gastrectomy and only TNM system was used. After June of 2005 (group 2), the surgeon himself dissected lymph nodal stations, allowing use of TNM and JGCA systems. Studied aspects were age, Borrmann classification, histological grade, venous or lymphatic invasion, depth of invasion, peritoneal cytology and type of gastrectomy. End points were number of dissected lymph nodes, number of positive lymph nodes and agreement between staging systems. Chi-square test and T-test were used for statistical analysis. Results - One hundred forty-five gastrectomies were performed, 76 in group 1 and 69 in group 2. In group 1, mean age was of 61 years and 59 years in group $2(P=0,12)$. Eighty per cent of tumors were advanced in both groups. Venous or lymphatic invasion and positive peritoneal cytology were more frequent in group 1 , $65.6 \%$ vs $35,3 \%(P=0,001)$ e $13.9 \%$ vs $3.1 \%(P=0,03)$, respectively. Borrmann classification, histological grade, Lauren classification and type of gastrectomy were not different between the groups. In group 1, mean number of lymph nodes was 32,7 and 37,35 in group $2(P=0,09)$. Rates of positive lymph nodes in groups 1 and 2 were $72.2 \%$ and $53 \%$, respectively $(P=0,02)$. Migration analysis of lymph node status $(\mathrm{N})$ realized only in group 2 (69 patients) showed agreement between TNM and JGCA in 50 patients $(72,5 \%)$. Using JGCA system, modification in 19 patients occurred (27,5\%), with upstaging in $13(18,8 \%)$ and downstaging in six (8,7\%). Conclusion - In this study, a tendency of increase in number of lymph nodes was verified when the surgeon himself dissected lymph nodal stations. JGCA system modified the lymph nodal staging in comparison to TNM system in $30 \%$ of all cases.

HEADINGS - Stomach neoplasms. Lymph node excision. Dissection. Neoplasm staging.

\section{INTRODUCTION}

In Japan, gastric cancer has been presented with high incidence and mortality for several decades, representing a serious public health problem. A great investment in population screening, interventions in epidemiological factors and surgical techniques, mainly lymphadenectomy, was carried out for disease control. In this setting, Japanese surgeons standardized a surgical approach that removes perigastric and celiac trunk lymph nodes called D2 dissection ${ }^{1}$.

An important aspect is the role of lymphadenectomy in gastric cancer staging. The Japanese Gastric Cancer Association (JGCA) rules a staging with $\mathrm{N}$ categories based on lymph nodal stations with specific anatomical

From the Department of Gastrointestinal Tumors and Pathology Division - Gastrointestinal Service, Araújo Jorge Hospital of the Goiás Association Against Cancer, Goiânia, GO, Brazil.

Correspondence to: Bruno José de Queiroz Sarmento, e-mail: bjqsarmento@yahoo.com.br sites along main vessels of upper abdomen. In $2^{\text {nd }}$ English Edition of Japanese Classification of Gastric Carcinoma ${ }^{1}$, lymph nodes are grouped by location of tumor into three compartments named N1, N2 and N3. This stratification allows identify patients with survival curves totally distinct, showing a strong prognostic factor ${ }^{2}$. However, this method demands a meticulous dissection, with separation of lymph node stations one and detailed pathological analysis.

In the Western, TNM system is used commonly and the International Union Against Cancer (UICC) published the last version in 2002. The $\mathrm{N}$ categories are based on number of positive lymph nodes and named N1 when 1-6 lymph nodes are positives, $\mathrm{N} 2$ when 7-15 positives lymph nodes and $\mathrm{N} 3$ when more than 15 lymph nodes are compromised ${ }^{3}$. In both systems, $\mathrm{N} 0$ was used when no lymph nodes were involved. The TNM system is more reproducible and easy to make than JGCA and allows an equal survival prediction than Japanese system ${ }^{2,3,4,5,6}$.

The purposes of this report were to verify if lymph- 
adenectomy with stations separation increases number of dissected lymph nodes and to establish comparison between TNM 2002 and JGCA 1998 evaluating lymph nodal status $(\mathrm{N})$.

\section{METHODS}

This is a retrospective analysis of patients that underwent curative gastrectomy and $\mathrm{D} 2$ dissection for adenocarcinoma between 2004 and 2006 in Araujo Jorge Hospital of the Goiás Association Against Cancer (ACCG). Between January of 2004 and June of 2005 (group 1), lymphadenectomy was performed en-bloc with gastrectomy and only TNM system was used. After June of 2005 (group 2 ), the surgeon himself dissected lymph nodal stations, allowing use of TNM and JGCA systems and a selective lymphadenectomy of station $16 \mathrm{~b} 1$ was carried out. One single pathologist reviewed all histological specimens in last period. Studied aspects were age, Borrmann status, histological grade, vascular or lymphatic invasion, depth of invasion (T), peritoneal cytology and type of gastrectomy. End points were number of dissected lymph nodes, number of positive lymph nodes and agreement between staging systems for $\mathrm{N}$ category. Chi-square test and T-test were used for statistical analysis. This study was accepted and approved by the review board of the institution.

TABLE 1- Clinical and histological aspects of 145 patients with gastric cancer.

\begin{tabular}{|c|c|c|c|}
\hline Characteristics & $\begin{array}{c}\text { Group } 1 \\
\text { (76 patients) }\end{array}$ & $\begin{array}{c}\text { Group } 2 \\
\text { (69 patients) }\end{array}$ & $P$ \\
\hline Mean age $(\mathrm{y})$ & 59 & 61 & 0.12 \\
\hline \multicolumn{4}{|l|}{ Localization } \\
\hline Upper & 5 & 5 & \multirow{4}{*}{0.97} \\
\hline Middle & 25 & 25 & \\
\hline Lower & 42 & 39 & \\
\hline Not available & 4 & -- & \\
\hline \multicolumn{4}{|l|}{ Depth of invasion (T) } \\
\hline$T 1$ & 12 & 20 & \multirow{5}{*}{0.14} \\
\hline$T 2$ & 18 & 16 & \\
\hline$T 3$ & 35 & 30 & \\
\hline$T 4$ & 6 & 2 & \\
\hline Not available & 5 & 1 & \\
\hline \multicolumn{4}{|l|}{ Histological grade } \\
\hline 1 and 2 & 33 & 29 & \multirow{3}{*}{0.54} \\
\hline 3 and undifferentiated & 36 & 39 & \\
\hline Not available & 7 & 1 & \\
\hline \multicolumn{4}{|c|}{ Venous and lymphatic invasion } \\
\hline Yes & 42 & 23 & \multirow{3}{*}{0.001} \\
\hline No & 22 & 42 & \\
\hline Not available & 12 & 4 & \\
\hline \multicolumn{4}{|l|}{ Peritoneal cytology } \\
\hline Positive & 6 & 2 & \multirow{3}{*}{0.03} \\
\hline Negative & 37 & 62 & \\
\hline Not available & 33 & 5 & \\
\hline \multicolumn{4}{|l|}{ Borrmann classification } \\
\hline 1 and 2 & 13 & 21 & \multirow{3}{*}{0.07} \\
\hline 3 and 4 & 58 & 46 & \\
\hline Not available & 5 & 2 & \\
\hline \multicolumn{4}{|l|}{ Lauren classification } \\
\hline Intestinal & 34 & 32 & \multirow{3}{*}{0.92} \\
\hline Diffuse & 36 & 35 & \\
\hline Not available & 6 & 2 & \\
\hline \multicolumn{4}{|l|}{ Type of gastrectomy } \\
\hline Distal & 45 & 48 & \multirow{3}{*}{0.23} \\
\hline Total & 30 & 21 & \\
\hline Not available & 1 & - & \\
\hline
\end{tabular}

\section{RESULTS}

One hundred forty-five gastrectomies were performed, 76 in group 1 and 69 in group 2 . In group 1, mean age was of 61 years and 59 years in group $2(P=0,12)$. Eighty per cent of tumors were advanced in both groups. Vascular or lymphatic invasion and positive peritoneal cytology were more frequent in group $1,65.6 \%$ vs $35,3 \%(P=0,001)$ e $13.9 \%$ vs. $3.1 \%$ $(P=0,03)$, respectively. Borrmann classification, histological grade, Lauren classification and type of gastrectomy were not different between the groups (Table1).

In group 1, mean number of lymph nodes was 32.7 and 37.3 in group $2(P=0.09)$. Rates of positive lymph nodes in groups 1 and 2 were $72.2 \%$ and $53 \%(P=0.02)$, respectively, and the mean number of positive lymph nodes was 9.46 in group 1 and 4.94 in group $2(P=0.01)$ (Table 2$)$.

In group 2, positive retroperitoneal lymph nodes were presented in $10.1 \%$ of patients $(7 / 69)$. In subgroup with 1-6 positive lymph nodes, two patients had positive para-aortic lymph nodes (10,5\% of N1 group in TNM 2002), both were Borrmann 3, with negative peritoneal cytology and histological grades 2 or 3 . In subgroup with more than 15 lymph nodes (N3 in TNM), fifty percent do not presented positive station $16 \mathrm{~b} 1$.

Analysis of lymph node $(\mathrm{N})$ status changing was realized only in group 2 (69 patients) and showed agreement between TNM and JGCA in 55 patients. Staging changing of $\mathrm{N}$ status occurred in $27,5 \%$ of the patients with upstaging in $13(18,8 \%)$ and downstaging in six $(8,7 \%)$ (Figure 1 and Table 3). The agreement is low in positive lymph nodes group $(61.1 \%)$ and a less favorable $\mathrm{N}$ status is usually obtained when JGCA 1998 system is used.

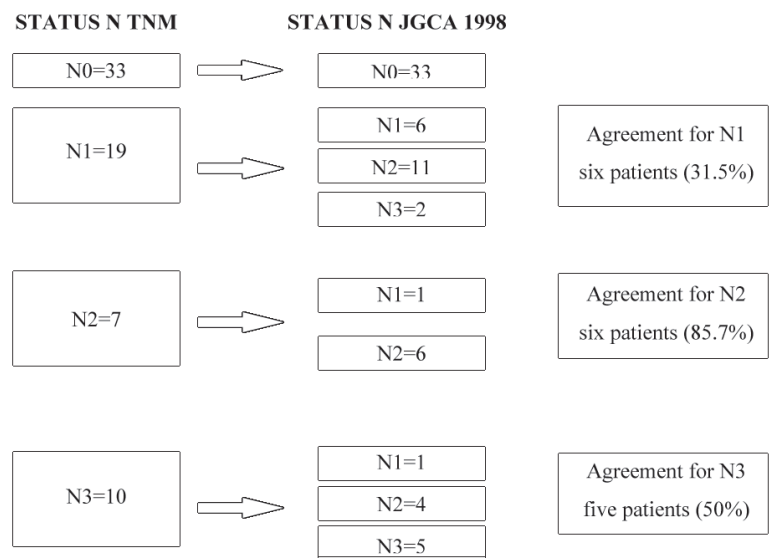

FIGURE 1- Analysis of lymph node status (N) changing in group 2 (69 patients).

TABLE 2 - Lymph nodal status of patients underwent gastrectomy and $\mathrm{D} 2$ dissection

\begin{tabular}{lccc}
\hline Characteristics & $\begin{array}{c}\text { Group 1 } \\
\text { (76 patients) }\end{array}$ & $\begin{array}{c}\text { Group 2 } \\
\text { (69 patients) }\end{array}$ & $\boldsymbol{P}$ \\
\hline $\begin{array}{l}\text { Lymph nodes dissected (mean) } \\
\text { Lymph nodal status }\end{array}$ & 32.71 & 37.35 & 0.09 \\
$\quad$ Positive & 55 & 36 & \\
$\quad$ Negative & 21 & 33 & 0.02 \\
Positive lymph nodes (mean) & 9.46 & 4.94 & 0.01 \\
\hline
\end{tabular}


TABLE 3 - Agreement between TNM 2002 and JGCA 1998 in group 2 (69 patients)

\begin{tabular}{lc}
\hline End points & Results \\
\hline Agreement for overall lymph nodes & $72.5 \%(50 / 69)$ \\
Agreement for positive lymph nodes & $47.2 \%(22 / 36)$ \\
Upstaging in positive lymph nodes group & $18.8 \%(13 / 36)$ \\
Downstaging positive lymph nodes group & $8.7 \%(6 / 36)$ \\
\hline
\end{tabular}

\section{DISCUSSION}

The results of $\mathrm{D} 2$ dissection were remarkable because provided better survival than D0-1 dissection when compared stage by stage ${ }^{2}$. However, these results are based only in retrospective analysis and Western randomized trials do not reproduce the same benefits with $\mathrm{D} 2$ dissection $^{7,8}$. Moreover, some questions about morbidity and mortality are always mentioned when a comparison involving lymph nodal dissection techniques is in discussion. Western and Eastern authors accept that D2 dissection can be performed with low rates of morbidity and mortality in specialized centers, by expertise surgeons and without pancreaticsplenectomy ${ }^{9,10,11}$.

The TNM and JGCA systems are essentially different in standardizing of lymph nodal status. In TNM, only the number of positive lymph nodes is applied, while JGCA valorizes localization of compromised lymph nodal station.

The Japanese conception is based in two principles: a) lymphatic drainage route must be patient-specific and lesion-specific in gastric cancer due to complicated lymphatic streams from stomach and jumping metastases occur in some cases by aberrant drainage patterns ${ }^{12}$; b) the anatomical site of lymph nodal metastasis is most important prognostic factor of survival ${ }^{1,2}$. In Japanese system, levels $\mathrm{N} 1$ and $\mathrm{N} 2$ are dissected with curative intention, however lymph nodal sample of level N3 is necessary to achieve a complete evaluation of lymph nodal status.

To establish the guideline of JGCA gastric cancer treatment in Araújo Jorge Hospital, a member (OMM) visited National Cancer Center and learned about surgical techniques, extension of lymph nodal dissection and general rules of gastric cancer study. The surgeon himself dissected lymph nodal stations in surgery room and sent to a single pathologist (EDM) for histopathological analysis. These modifications produced an increase in number of dissected lymph nodes from 32.72 to 37.35 ( $P=0.09)$. However, this result is lower than Eastern results, where more than 40 lymph nodes are dissected usually ${ }^{13}$, showing a learning curve in development.

Positive para-aortic lymph nodes are found $17-40 \%$ of patients and long-term survival is poor ${ }^{2,14,15}$. The more important aspect in this series is presence of metastasis $\mathrm{N} 3$ in patients with few positive lymph nodes, a rare finding in literature (N1 in TNM staging). Two consequences must be considerate: an inadequate staging (downstaging) can occur with limited lymphadenectomy, and possibility of cure with extended lymph nodal dissection when exist occult para-aortic metastases.

In patients with 7-15 positive lymph nodes, none of them presented para-aortic metastasis, but only seven patients were in this subgroup. Another interesting finding was upstaging in patients with more than 15 positive lymph nodes. Some patients in this subgroup present N1-2 disease, therefore potentially cured with curative D2 dissection.

A sampling of station 16 can provide valuable information about gastric cancer staging and produce a disagreement between TNM and JGCA systems (38.9\% for positive lymph nodes in this series). The future tendency points to a new system that will be consist of two actual systems, but number of positive lymph nodes will be more important and localization as a secondary factor for stratification of subgroups $^{3,16}$.

\section{CONCLUSIONS}

In this study, a tendency of increase in number of lymph nodes was verified when the surgeon himself dissected lymph nodal stations. JGCA system modified the lymph nodal staging in comparison to TNM system in 30\% of all cases. Moreover, patients with a few positive lymph nodes (N1 in TNM) can be compromised by retroperitoneal metastasis (station 16b1), and not all patients with N3 status in TNM have retroperitoneal disease. 
Sarmento BJQ, Brito AM, Cardoso DMM, Campoli PMO, Silva OQ, Santana-Filho JB, Barreto PAQ, Machado MG, A-Filho AVA, Mota ED, Mota OM. Linfadenectomia D2 com amostragem para-aórtica melhora o estadiamento linfonodal do câncer gástrico. ABCD Arq Bras Cir Dig 2007;20(3):161-4.

RESUMO - Racional - O papel da linfadenectomia no estadiamento de câncer gástrico é de grande importância quando lidando com câncer gástrico. Objetivo - Verificar se a linfadenectomia com estações linfonodais separadas aumenta o número da dissecção de linfonodos e estabelecer comparação entre o TNM 2002 e o JGCA 1998, avaliando o status dos linfonodos (N). Métodos - Foi realizada análise retrospectiva de pacientes que foram submetidos à gastrectomia curativa e dissecções do tipo D2 para adenocarcinomas, entre 2004 e 2006. Entre janeiro de 2004 e junho de 2005 (grupo 1), a linfadenectomia foi realizada em flape único com gastrectomia e somente o sistema TNM foi utilizado. Após junho de 2005 (grupo 2), o cirurgião realizou a dissecção de estações linfonodais, permitindo o uso dos sistemas TNM e JGCA. Os aspectos estudados e analisados foram idade, classificação de Borrmann, grau histológico, invasão venosa ou linfática, profundidade da invasão, citologia peritoneal e tipo de gastrectomia. Foram analisados o número de linfonodos dissecados, o número de linfonodos positivos e o entendimento entre os sistemas de estadiamento. $\mathrm{O}$ teste do Chi-quadrado e teste- $t$ foram utilizados para realizar a análise estatística. Resultados - Foram realizadas 145 gastrectomias, sendo 76 no grupo 1 e 69 no grupo 2. A idade média referente ao grupo 1 foi de 61 anos e de 59 no grupo $2(P=0,12)$. Em ambos os grupos $80 \%$ dos tumores eram avançados. Invasão venosa e linfática e citologia peritonial positiva foram mais freqüentes no grupo $1,65.6 \%$ vs $35.3 \%(P=0,001)$ e $13.9 \%$ vs 3.1\% $(P=0,03)$, respectivamente. A classificação de Borrmann, grau histológico, classificação de Lauren e tipo de gastrectomia não foram diferentes entre os grupos. No grupo 1, a média de linfonodos foi de 32.7 e no grupo 2 de $37.35(P=0,09)$. O índice de linfonodos positivos nos grupos 1 e 2 foi de $72.2 \%$ e $53 \%$, respectivamente $(P=0,02)$. A análise de migração do status de linfonodos $(\mathrm{N})$ foi realizada no grupo 2 (69 pacientes) em concordância com o TNM e JGCA em 50 pacientes (72.5\%). Ao utilizar o sistema JGCA, ocorreram modificações em 19 pacientes (27.5\%), com aumento de estadiamento em 13 (18.8\%) e diminuição em 6 (8.7\%). Conclusão - Neste estudo, foi verificada tendência ao aumento do número de linfonodos quando o cirugião realizou, ele mesmo, a dissecção das estações linfonodais. O sistema JGCA modificou o estadiamento linfonodal quando comparado ao sistema TNM em $30 \%$ de todos os casos.

DESCRITORES - Neoplasias gástricas. Excisão de linfonodo. Dissecação. Estadiamento de neoplasias.

\section{REFERENCES}

1. Bonenkamp JJ, Hermans J, Sasako M, van de Velde CJ, Welvaart K, Songun I, Meyer S, Plukker JT, Van Elk P, Obertop H, Gouma DJ, van Lanschot JJ, Taat CW, de Graaf PW, von Meyenfeldt MF, Tilanus H; Dutch Gastric Cancer Group. Extended lymph-node dissection for gastric cancer. N Engl J Med. 1999;340:908-14.

2. Cheng LY, Zhong SZ, Huang ZH. Sentinel lymph node concept in gastric cancer with solitary lymph node metastasis. World J Gastroenterol. 2004;10:30535 .

3. Cuschieri A, Weeden S, Fielding J, Bancewicz J, Craven J, Joypaul V, Sydes M, Fayers P. Patient survival after D1 and D2 resections for gastric cancer: long-term results of the MRC randomized surgical trial. Surgical Co-operative Group. Br J Cancer. 1999;79:1522-30.

4. Degiuli M, Sasako M, Calgaro M, Garino M, Rebecchi F, Mineccia M, Scaglione D, Andreone D, Ponti A, Calvo F, Italian Gastric Cancer Study Group. Morbidity and mortality after D1 and D2 gastrectomy for cancer: interim analysis of the Italian Gastric Cancer Study Group (IGCSG) randomised surgical trial. Eur J Surg Oncol. 2004;30:303-8.

5. Degiuli M, Sasako M, Ponzetto A, Allone T, Soldati T, Calgaro M, Balcet F, Bussone R, Olivieri F, Scaglione D, Danese F, Morino M, Calderini P, Capussotti L, Fronda G, Garavoglia M, Locatelli L, Dellepiane M, Rossini FP, Calvo F. Extended lymph node dissection for gastric cancer: results of a prospective, multi-centre analysis of morbidity and mortality in 118 consecutive cases. Eur J Surg Oncol. 1997;23:310-4.

6. Fujii K, Isozaki H, Okajima K, Nomura E, Niki M, Sako S, Izumi N, Mabuchi $\mathrm{H}$, Nishiguchi K, Tanigawa N. Clinical evaluation of lymph node metastasis in gastric cancer defined by the fifth edition of the TNM classification in comparison with the Japanese system. Br J Surg. 1999;86:685-9.

7. Ichikura T, Tomimatsu S, Uefuji K, Kimura M, Uchida T, Morita D, Mochizuki H. Evaluation of the New American Joint Committee on Cancer/International Union Against Cancer classification of lymph node metastasis from gastric carcinoma in comparison with the Japanese classification. Cancer. 1999;86:5538.
8. Japanese Gastric Cancer Association. Japanese classification of gastric carcinoma. 2nd English ed. Gastric Cancer. 1998;1:10-24.

9. Japanese Gastric Cancer Association. Registration Committee; Maruyama K, Kaminishi M, Hayashi K, Isobe Y, Honda I, Katai H, Arai K, Kodera Y, Nashimoto A. Gastric cancer treated in 1991 in Japan: data analysis of nationwide registry. Gastric Cancer. 2006;9:51-66.

10. Kato M, Saji S, Kawaguchi Y, Kunieda K, Sugiyama Y, Takagi Y, Hiraoka T, Kumazawa I, Adachi T. A comparison of the prognostic significance between the number of metastatic lymph nodes and nodal stage in gastric carcinoma. Hepatogastroenterology. 1999;46:3281-6.

11. Lewis WG, Edwards P, Barry JD, Khan S, Dhariwal D, Hodzovic I, Allison $\mathrm{MC}$, Shute K. D2 or not D2? The gastrectomy question. Gastric Cancer. 2002;5:29-34.

12. Nakane Y, Okamura S, Masuya Y, Okumura S, Akehira K, Hioki K. Incidence and prognosis of para-aortic lymph node metastasis in gastric cancer. Hepatogastroenterology. 1998;45:1901-6.

13. Okamoto K, Sawai K, Minato H, Yada H, Shirasu M, Sakakura C, Otsuji E, Kitamura K, Taniguchi H, Hagiwara A, Yamaguchi T, Takahashi T. Number and anatomical extent of lymph node metastases in gastric cancer: analysis using intra-lymph node injection of activated carbon particles (CH40). Jpn J Clin Oncol. 1999;29:74-7.

14. Pedrazzani C, deManzoni G, Marrelli D, Giacopuzzi S, Corso G, Bernini M, Roviello F. Nodal staging in adenocarcinoma of the gastro-esophageal junction. Proposal of a specific staging system. Ann Surg Oncol. 2007;14:299-305.

15. Saito H, Fukumoto Y, Osaki T, Fukuda K, Tatebe S, Tsujitani S, Ikeguchi M. Prognostic significance of level and number of lymph node metastases in patients with gastric cancer. Ann Surg Oncol. 2007 Jan 24; [Epub ahead of print]

16. Yonemura Y, Katayama K, Kamata T, Fushida S, Segawa M, Ooyama S, Miwa K, Miyazaki I. Surgical treatment of advanced gastric cancer with metastasis in para-aortic lymph node. Int Surg. 1991;76:222-5.

Conflito de interesse: não há Fonte financiadora: não há Recebido para publicação em: 17/04/2007 Aceito para publicação em: 05/06/2007 